medRxiv preprint doi: https://doi.org/10.1101/2020.07.21.20159186; this version posted July 27, 2020. The copyright holder for this preprint

(which was not certified by peer review) is the author/funder, who has granted medRxiv a license to display the preprint in perpetuity.

It is made available under a CC-BY-NC 4.0 International license .

\title{
Epidemiological, clinical and genomic insights into the ongoing diphtheria outbreak in
} Yemen

Edgar Badell1,2, Abdulilah Alharazi3, Alexis Criscuolo4, The NCPHL diphtheria outbreak working group\#, Noemie Lefrancq5, Valerie Bouchez1, Julien Guglielmini4, Melanie Hennart1,6, Annick Carmi-Leroy1,2, Nora Zidane1, Marine Pascal-Perrigault1, Manon Lebreton1, Helena Martini7, Henrik Salje5,8, Julie Toubiana1,2,9, Fekri Dureab10, Ghulam Dhabaan11,* and Sylvain Brisse1,2,*

\#The NCPHL diphtheria outbreak working group: Abdulaziz A. Rawah, Mohammed A. Aldawla, Ekram M. Al-Awdi, Nabila M. Al-Moalmy, Khaled A. Almoayed, Huda Z. Al-Shami, Ali A. Al-Somainy

\section{Affiliations:}

1 Institut Pasteur, Biodiversity and Epidemiology of Bacterial Pathogens, Paris, France

2 Institut Pasteur, National Reference Center for Corynebacteria of the diphtheriae complex, Paris, France

3 National Centre of the Public Health Laboratories (NCPHL), Sana'a, Yemen

$4 \mathrm{Hub}$ de Bioinformatique et Biostatistique ? Département Biologie Computationnelle, Institut Pasteur, USR 3756 CNRS, Paris, France

5 Mathematical Modelling of Infectious Diseases Unit, Institut Pasteur, UMR2000, CNRS, Paris, France

6 Sorbonne Université, Collège doctoral, F-75005 Paris, France

7 Department of Microbiology, National Reference Centre for toxigenic corynebacteria, Universitair Ziekenhuis Brussel, Vrije Universiteit Brussel (VUB), Laarbeeklaan 101, 1090 Brussels, Belgium

8 Department of Genetics, University of Cambridge, Cambridge, UK 9 Université de Paris, General Paediatrics and Paediatric Infectious Diseases Department, Hôpital Necker-Enfants malades, APHP, Paris, France

10 Institute for Research in International Assistance, Akkon Hochschule, Berlin, Germany, 2Heidelberg Institute of Global Health, Heidelberg, Germany 11 Mount Sinai Hospital, University Health Network, University of Toronto, Toronto, Canada *Correspondence: 
medRxiv preprint doi: https://doi.org/10.1101/2020.07.21.20159186; this version posted July 27, 2020. The copyright holder for this preprint (which was not certified by peer review) is the author/funder, who has granted medRxiv a license to display the preprint in perpetuity. It is made available under a CC-BY-NC 4.0 International license .

32 Sylvain Brisse. Institut Pasteur, Biodiversity and Epidemiology of Bacterial Pathogens, Paris,

33 France. E-mail: sylvain.brisse@pasteur.fr; Tel: +33 1456883 34;

34 Ghulam Dhabaan: Mount Sinai Hospital, University Health Network, University of Toronto,

35 Toronto, Canada. Ghulam.Dhabaan@utoronto.ca ; Tel: +1 6479498012

36 Keywords: diphtheria, outbreak, epidemiology, phylogenetics, antimicrobial resistance,

37 genomic sequencing, evolutionary rate, Yemen

38 Running Title: Diphtheria in Yemen 
medRxiv preprint doi: https://doi.org/10.1101/2020.07.21.20159186; this version posted July 27, 2020. The copyright holder for this preprint (which was not certified by peer review) is the author/funder, who has granted medRxiv a license to display the preprint in perpetuity.

It is made available under a CC-BY-NC 4.0 International license.

\section{Abstract}

Background. An outbreak of diphtheria, declared in Yemen in October 2017, is still ongoing. Methods. Probable cases were recorded through an electronic diseases early warning system. Microbiological culture, genomic sequencing, antimicrobial susceptibility and toxin production testing were performed.

Findings. The Yemen diphtheria outbreak developed in three epidemic waves, which affected nearly all governorates (provinces) of Yemen, with 5701 probable cases and 330 deaths (October 2017 - April 2020). The median age of patients was 12 years (range, 0.1780). Virtually all outbreak isolates ( 40 of 43 tested ones) produced the diphtheria toxin. We observed low level of antimicrobial resistance to penicillin. We identified six separate Corynebacterium diphtheriae phylogenetic sublineages, three of which are genetically related to isolates from Saudi Arabia and Somalia. The predominant sublineage was resistant to trimethoprim and was associated with unique genomic features, more frequent neck swelling $(p=0.002)$ and a younger age of patients $(p=0.06)$. Its evolutionary rate was estimated at $1.67 \times 10^{-6}$ substitutions per site $y^{-1}{ }^{-1}$, placing its most recent common ancestor in 2015, and indicating silent circulation of $C$. diphtheriae in Yemen earlier than outbreak declaration.

Interpretation. We disclose clinical, epidemiological and microbiological characteristics of one of the largest contemporary diphtheria outbreaks and demonstrate clinically relevant heterogeneity of $\boldsymbol{C}$. diphtheriae isolates, underlining the need for laboratory capacity and real-time microbiological analyses to inform prevention, treatment and control of diphtheria.

Funding. This work was supported by institutional funding from the National Centre of the Public Health Laboratories (Sanaa, Yemen) and Institut Pasteur (Paris, France) and by the French Government Investissement d'Avenir Program. 
medRxiv preprint doi: https://doi.org/10.1101/2020.07.21.20159186; this version posted July 27, 2020. The copyright holder for this preprint (which was not certified by peer review) is the author/funder, who has granted medRxiv a license to display the preprint in perpetuity.

It is made available under a CC-BY-NC 4.0 International license .

64

65

66

67

68

69

\section{Introduction}

Diphtheria is a severe infection that typically affects the upper respiratory tract, potentially leading to pseudomembrane formation, neck swelling and suffocation [1, 2]. In addition, diphtheria toxin production by some $C$. diphtheriae strains can cause damage to the heart and other organs. Non-toxigenic strains can also cause invasive infections [3]. Before large scale vaccination, which mainly targets the toxin and is highly effective in preventing the disease, diphtheria was a major cause of death in children [2]. Large outbreaks of diphtheria are often observed following disruption to vaccination programs, as occurred in the Soviet Union in the 1990s [4] and more recently in the Rohingya refugee population in Bangladesh [5] and in Venezuela [6]. Diphtheria is still observed occasionally in high-income countries, in particular among migrants $[7,8]$.

In Yemen, where civil war has been raging since March 2015, a large outbreak of diphtheria was recognized in October 2017 [9, 10][11]. While a vaccination campaign targeting 300,000 children began in late November 2018, with plans to scale up to 3 million children and young adults in December, the ongoing conflict has complicated vaccination catch-up efforts [12, 13]. Before this outbreak, diphtheria was considered endemic in Yemen, with an average of 50 suspected cases reported annually since 2000 [14]. The last documented outbreak of diphtheria in this country occurred in 1981-82, with a total of 149 cases with no death. Yemen is currently also affected by other epidemic diseases including cholera [15] and COVID-19 [16, 17]. As of May 2020, the diphtheria outbreak was still ongoing [18]. The early epidemiology of the outbreak was described $[9,10]$, but virtually no data have been reported on the clinical and microbiological characteristics of the outbreak.

Besides vaccination, a critical component of diphtheria management is serotherapy. Unfortunately, diphtheria antitoxin is not readily available in Yemen, as in most world countries [19]. Antimicrobial treatment is also indicated for patient care and to avoid transmission, with penicillin and erythromycin being recommended as first-line therapeutic agents [20][2].

Here we report on the clinical, epidemiological and microbiological features of the ongoing Yemen diphtheria outbreak. 
medRxiv preprint doi: https://doi.org/10.1101/2020.07.21.20159186; this version posted July 27, 2020. The copyright holder for this preprint (which was not certified by peer review) is the author/funder, who has granted medRxiv a license to display the preprint in perpetuity.

It is made available under a CC-BY-NC 4.0 International license .

\section{Results}

94 Epidemiology and clinical features of the Yemen diphtheria outbreak, 2017-2020

95 Large numbers of probable cases were recorded in 2017 ( $n=560), 2018$ ( $n=2606), 2019$ 96 ( $n=2004$ ) and in 2020 (up to week 17: $n=649$ ). Altogether, 5701 cases including 330 deaths 97 were reported up to April 26th, 2020, corresponding to a case fatality rate of $5.8 \%$.

98 Between 2017 and 2020 there were three major waves of cases (Figure 1A). The first wave 99 occurred from October 2017 until June 2018 with a peak on week 6 of 2018. The second 100 wave was flatter and lasted from June 2018 until June 2019. The third wave started in June 1012019 and reached its peak in October 2019, with more than 80 cases/week by that time.

102 The outbreak affected nearly all governorates of Yemen (Figure 1, Table S3). However, some 103 governorates were more affected and the two first epidemic waves had distinctive 104 geographic signatures (Figure 1D,E). The outbreak started in October 2017 in Ibb, where 288 105 cases (52\% of the total 2017 cases) were registered; while Al Hodeidah recorded 60 cases 106 (11\%) in this year. In 2018, 2606 cases were registered in 21 governorates, with $64 \%$ of the 107 cases registered in 5 governorates: Hajja (395 cases, 15\%), Al Hodeidah (338, 13\%), Sana'a

108 (339, 13\%), Ibb $(324,12 \%)$ and the capital city of Sana'a $(276,11 \%)$. Last, the distribution of 109 reported cases in 2019 shows that $60 \%$ of cases occurred in four governorates: Al Hodeida 110 (371 cases, 18\%), Hajjah (327 cases, 16\%), Sadah (297 cases, 15\%) and Sana'a (226 cases, 111 11\%).

112

113 Clinical data available for 888 patients (February 2018 - November 2019) showed that 114 patients were more likely to be female (55\%), and their median age was 12 (range, 0-80) 115 years (Figure 2A). Of the 750 patients with available data, 434 (58\%) reported a history of 116 previous vaccination against diphtheria. The vaccinated proportion of patients did not 117 change between 2018 and 2019 (57\% vs. 59\%, p=0.49). The median age of vaccinated 118 patients was lower (10 years, range $0.17-45$ ) than that of non-vaccinated patients (13 years, 119 range $0.17-80 ; p<0.001)$. The age distribution of cases was available for the first two 120 epidemic waves. We found that the median age of infection was 12 years old; however, the 121 attack rate was highest in those 5-15 years in age as compared to other groups. While the 122 attack rate was largely constant between the first two years in those over 5 years old, there 123 was a marked reduction in children 0-4 years between the two waves (Figure 2B; Figure S1). 
medRxiv preprint doi: https://doi.org/10.1101/2020.07.21.20159186; this version posted July 27, 2020. The copyright holder for this preprint (which was not certified by peer review) is the author/funder, who has granted medRxiv a license to display the preprint in perpetuity.

It is made available under a CC-BY-NC 4.0 International license .

124 Almost all patients ( $\mathrm{n}=818 / 841,97 \%$ ) had fever. Pseudomembrane was present in $787 / 839$

125 (94\%), signs of laryngitis in 548/784 (31\%), neck swelling in 456/769 (59\%) and tonsillitis in

126 821/836 (98\%) patients with available data. Difficulty to swallow and to breathe were

127 observed in 710 (86\%) and 399 (51\%) patients, respectively. No difference in disease

128 expression was observed between vaccinated and non-vaccinated patients. Most patients

$129(n=634 / 790,80 \%)$ were reported to be under antibiotic therapy at the time of throat

130 sampling.

131

132 Microbiological confirmation of cases was tested for 888 samples referred to the NCPHL

133 from 2018 to 2020. Of the 836 cases with available results, 340 (41\%) were microbiologically

134 confirmed by a positive $C$. diphtheriae culture. The temporal and geographic distributions of

135 tested and confirmed cases were similar (Figure 1B-C).

136

137 Phylogenetic diversity of $C$. diphtheriae from Yemen and their relationships with global

138 isolates

139 A random selection of $98 C$. diphtheriae positive cultures were transferred to Institut Pasteur

140 (Paris, France) for external confirmation and sequencing. Two cultures (YEM0065 = YE-

141 NCPHL-647L) and YEM0070 = YE-NCPHL-647S) with distinct colony morphologies had been

142 isolated from a single sample. We confirmed by qPCR [21] that 47 cultures carried genetic

143 material of $C$. diphtheriae, 43 of which could be isolated in pure culture.

144 Detection of the diphtheria toxin tox gene was positive in 40 out of 43 isolates; 3 isolates

145 were tox-negative by GPCR (Table S1), which was confirmed by genomic analyses. The Elek

146 in-vitro test for diphtheria toxin production demonstrated that 39 tox-positive isolates

147 produced the toxin (YEM0035 was Elek negative).

148 Phylogenomic analyses revealed the existence of six sublineages (labeled A to F, Figure 3).

149 One of them, called sublineage A, comprised 30 (70\%) isolates (Table S1). The six

150 sublineages were unrelated to each other, as evidenced by their scattered positions in a

151 global phylogenetic tree of $C$. diphtheriae (Figure S2), demonstrating multiple occurrences of

152 diphtheria re-emergence or introductions into Yemen.

153 Sublineages A and B were of biovar Gravis, whereas the others were biovar Mitis. The 154 detection of the spuA gene, coding for a putative alpha-1,6-glycosidase [22] associated with 155 the glycogen positive phenotype of biovar Gravis, was consistent with these biochemical 
medRxiv preprint doi: https://doi.org/10.1101/2020.07.21.20159186; this version posted July 27, 2020. The copyright holder for this preprint

156 assignations (Figure $\mathbf{3 A}$ ) and showed that Yemen isolates belonged to two deep lineages of

157 C. diphtheriae marked by the presence or absence of this gene (Figure S2) as recently

158 reported [23].

159 Genotyping of the $C$. diphtheriae Yemen isolates by 7-gene multilocus sequence typing 160 (MLST, Table S1) revealed that sublineage A isolates belonged to ST384. The single 161 previously reported ST384 isolate (DIFT045; https://pubmlst.org/cdiphtheriae/) was isolated 162 in Belgium in 2016, and was collected in a patient who had close contact with a person 163 having traveled back from Saudi Arabia [24]. This observation hinted to a possible 164 epidemiological link between the main Yemen outbreak lineage and Saudi Arabia. To 165 reinforce this hypothesis, the genome of DIFT045 was sequenced, confirming its very close 166 genetic relatedness with sublineage A (Figure 3). Based on the global phylogenetic tree 167 (Figure S2), sublineage A was the Yemenite sublineage closest to the ex-Soviet Union 1990s 168 outbreak strain [25]. However, the large genetic distance between sublineage A isolates and 169 strain NCTC 13129, the reference for the ST8 ex-Soviet Union outbreak, rules out a direct 170 epidemiological link between the two outbreaks.

171 Sublineage $\mathrm{E}$ isolates were closely related to two isolates collected from migrants from 172 Somalia [26], and sublineage $C$ isolates were closely related to isolates from siblings with a 173 Somalian origin [7]. Other Yemen sublineages were not phylogenetically closely related to 174 isolates from previously sequenced C. diphtheriae isolates (Figure S2).

175 We defined the genomic diversity of Yemen and DIFT045 isolates by clustering their protein176 coding genes (Figure S3). A total of 3619 gene families were identified, 1790 of which were 177 shared by all isolates (core genome). Genomes had 2277 genes on average (range 2234178 2427), and each of the six sublineages possessed 54 to 140 genes not observed in the other 179 sublineages, underlying the potential for large phenotypic variation among them.

\section{Microevolution of sublineage A}

182 We subdivided sublineage A into two branches, with branch A.1 being further subdivided 183 into A.1.1 and A.1.2 (Figure 3). The latter comprised the Belgium isolate DIFT045 and 184 YEM0063. The epidemiologically predominant branch A.1 was highly homogeneous 185 genetically, with a maximum of 86 genome-wide SNPs among its members (observed 186 between YEM0063 and YEM0089), indicating that A.1 isolates share a recent common 187 ancestor. The amount of nucleotide substitutions observed in isolates of this sublineage was 
medRxiv preprint doi: https://doi.org/10.1101/2020.07.21.20159186; this version posted July 27, 2020. The copyright holder for this preprint (which was not certified by peer review) is the author/funder, who has granted medRxiv a license to display the preprint in perpetuity.

It is made available under a CC-BY-NC 4.0 International license .

188 significantly related to their isolation time (Figure S4), demonstrating measurable evolutionary divergence (Figure 3B), with a substitution rate estimated at $1.67 \times 10^{-6}$

190 substitutions per site per year $\left(95 \% \mathrm{Cl}=3.98 \times 10^{-7}-2.99 \times 10^{-6}\right)$. The last common ancestor

191 of A.1.1 was estimated to have existed in March 2015 (Nov. 2003 - Sep. 2016). These results

192 indicate that this subgroup of Yemenite diphtheria isolates circulated and diversified silently

193 within the country several years before the diphtheria outbreak declaration in 2017.

194

\section{Antimicrobial susceptibility of Yemen $C$. diphtheriae isolates}

196 Antimicrobial susceptibility data were heterogeneous among Yemen sublineages (Figure 3,

197 Table S2). Importantly, full susceptibility or only low levels of penicillin resistance were 198 observed for all Yemen diphtheria isolates. While eight isolates (18.6\%) were penicillin 199 resistant (Table S2), the two most resistant isolates had a minimal inhibitory concentration 200 (MIC) of $0.25 \mathrm{mg} / \mathrm{L}$, which is only twice the clinical breakpoint of resistance $(>0.125 \mathrm{mg} / \mathrm{L})$. 201 Further, the MIC50 and MIC90 of penicillin were 0.094 and $0.19 \mathrm{mg} / \mathrm{L}$, respectively (Table 202 S2). Amoxicillin and erythromycin were also active against all isolates, as were many other 203 tested molecules. Resistance to ciprofloxacin (but not to moxifloxacin) was observed in two 204 isolates, which had a D93G change in the quinolone-resistance determining region of their 205 gyrA gene. Resistance to trimethoprim was found in $32(74.4 \%)$ isolates, including most 206 members of sublineage A (Figure 3), but none was resistant to the combination of this agent 207 with sulfamethoxazole (Table S2). Four isolates possessed homologs of the sul1 gene, and decreased phenotypic susceptibility to sulfonamide was observed in two of these. Resistance

209 to tetracycline was observed in 11 isolates, which all belonged to minor sublineages whereas

210 sublineage A was susceptible (Figure 3A); five of these isolates possessed known tetracycline 211 resistance genes encoding the tet33 efflux pump or the tetO ribosomal protection protein.

212 Finally, the two isolates of sublineage B possessed an aadA2 gene coding for an ANT( 3 ") 213 aminoglycoside modifying enzyme targeting spectinomycin and streptomycin. Accordingly, 214 these two isolates were susceptible to gentamicin and kanamycin.

216 Association of sublineage A with clinical signs and genomic features potentially linked to 217 virulence

218 Clinical features of $C$. diphtheriae infections caused by isolates from sublineage A were 219 distinctive, with patients tending to be younger $(p=0.06)$ and with more frequent swollen 
medRxiv preprint doi: https://doi.org/10.1101/2020.07.21.20159186; this version posted July 27, 2020. The copyright holder for this preprint (which was not certified by peer review) is the author/funder, who has granted medRxiv a license to display the preprint in perpetuity. It is made available under a CC-BY-NC 4.0 International license .

220 neck ( $p=0.002$; Table 1). We screened the genomic sequences for the presence of putative 221 pathogenicity-associated genes. Sublineage A isolates possessed genes iusABC coding for an 222 ABC-type iron uptake system, the chtAB genes that are homologous to htaAB genes for 223 hemin binding, a pathogenicity island of $C$. diphtheriae called PICD-11 [27] comprising a 224 putative collagen binding protein suggested to be associated with cutaneous or invasive 225 infections [28], and the spaABC-strA and spaDEF-strBC gene clusters coding for two distinct 226 types of fimbriae (Figure 3). In contrast to sublineage A, most other Yemen isolates did not 227 harbor the above gene clusters. In turn, their genomes comprised genes sidBA-ddpABC for 228 putative siderophore biosynthesis, irp1ABCD for a putative ABC-type iron transporter [29] 229 and the $\operatorname{irp2ABCDEFGHI}$ and $\operatorname{irp} 2 J K L M N$ operons. Genes coding for SpaH fimbriae were 230 absent from all Yemen genomes. Broader putative virulence genes variation was observed at 231 the global scale, with a marked dichotomy between the two major lineages defined by gene 232 spuA (Figure S2).

233 We further searched for sublineage A.1-enriched genes by analyzing the pangenome of 234 Yemen isolates together with the sublineage A-related strain NCTC13129. 77 genes were 235 enriched in sublineage A.1 (present in $>95 \%$ A.1 isolates, and absent in $>85 \%$ of other 236 isolates), among which six were uniquely found in all members of this sublineage (Table S4). 237 Among these, one gene was annotated as a 5-formyltetrahydrofolate cyclo-ligase gene, the 238 homolog of which was previously shown to increase the resistance level to antifolates in 239 Mycobacterium smegmatis and Escherichia coli [30]. Further analyses showed that this gene 240 is in fact found in all Corynebacterium genomes, but the sublineage A.1 version is shorter 241 (417 versus a median of 585 bp among all Corynebacterium species). Of note, the size of this 242 gene does not vary at all in $C$. diphtheriae except for isolates of the Yemen outbreak 243 sublineage A (585 bp). A possible causal link of this genetic truncation with resistance to 244 trimethoprim, which was observed mostly in sublineage A (but not solely A.1; Figure 3), will 245 be interesting to investigate in future studies. 
medRxiv preprint doi: https://doi.org/10.1101/2020.07.21.20159186; this version posted July 27, 2020. The copyright holder for this preprint (which was not certified by peer review) is the author/funder, who has granted medRxiv a license to display the preprint in perpetuity.

It is made available under a CC-BY-NC 4.0 International license .

\section{Discussion}

The outbreak of diphtheria in Yemen was first notified in October 2017 and its early epidemiology was described $[9,11,14]$. Here, we provide an update on the epidemiological situation, a clinical description of the characteristics of recorded suspected cases, and detailed information on microbiological features of $C$. diphtheriae outbreak isolates.

Based on currently reported probable cases, the Yemen diphtheria outbreak is one of the largest $C$. diphtheriae contemporaneous outbreaks. We identified three discernible waves with distinctive geographic signatures. We note that reporting is very likely to be an underestimate in the context of the Yemen health care disruption, and to be uneven geographically given the heterogeneity in the continuation of health care facility operations. Nevertheless, the eDEWS system [31] proved invaluable in the surveillance of diphtheria in the conflict context.

Clinical characteristics were typical of diphtheria in terms of laryngeal manifestations, pseudomembrane presence and neck swelling [32]. Yemenite patients were mostly young, which is also typical, with the exception of the ex-Soviet Union event [4]. Vaccination is highly effective against the clinical expression of toxigenic $C$. diphtheriae infections, and countries with high population coverage have virtually eliminated endemic diphtheria [2]. In Yemen, the vaccination coverage of the third dose of pentavalent vaccine in 2017 and 2018 (Figure S5) was $<80 \%$ in several governorates, which is considered as insufficient to reach population immunity [33]. We found that more than $50 \%$ of patients were reported to be previously vaccinated. We did not have access to the exact vaccination status, but we can assume that this observation reflects an incomplete vaccination without booster. This might also explain the median age $>5$ years of patients, comparable to other outbreaks in populations where vaccination was incomplete [34][35]. From November 2017 to March 2018, a mass vaccination campaign targeted nearly 2.7 million children aged 6 weeks to 15 years in 11 governorates [36]. Here we found that from the first to the second wave, there was a reduction in infection risk in 0-4 years old, consistent with some success from the mass immunization program. In 2019, diphtheria vaccination was further conducted in 186 districts of the 12 Northern governorates [37], with 1.2 million children 6 weeks to 5 years of age vaccinated with the Penta vaccine and 2.2 million children 5-15 years with the $\mathrm{Td}$ vaccine. Vaccination against diphtheria in selected districts of Southern governorates and 
medRxiv preprint doi: https://doi.org/10.1101/2020.07.21.20159186; this version posted July 27, 2020. The copyright holder for this preprint (which was not certified by peer review) is the author/funder, who has granted medRxiv a license to display the preprint in perpetuity. It is made available under a CC-BY-NC 4.0 International license.

277 Sa'adah has started in July 2020. However, despite efforts to control the disease, cases were 278 still being reported in 2020 , and future studies will be needed to evaluate their effect.

279 This work represents a unique genomic analysis of a large contemporaneous outbreak of 280 diphtheria. A prominent observation was that at least six phylogenetic sublineages, 281 ancestrally unrelated within the global diversity of $C$. diphtheriae, contributed to the 282 resurgence of diphtheria in Yemen. This important observation shows that strains with 283 distinctive genomic and phenotypic characteristics can coexist within a single diphtheria outbreak. The multiplicity of strains reflects a silent diversity reservoir of $\boldsymbol{C}$. diphtheriae despite vaccination, which is designed to protect against disease expression rather than colonization and transmission. Antimicrobial resistance remains rare in C. diphtheriae [38], and our results show that the main recommended agents (penicillin $G$, aminopenicillin and erythromycin) are active against Yemen $C$. diphtheriae despite a low-level penicillin resistance in some isolates. However, antimicrobial susceptibility profiles were heterogeneous, with a strong phylogenetic sublineage effect, and were largely concordant with genomic data, implying a possible future role for molecular testing of antimicrobial resistance in C. diphtheriae.

293 Our work also uncovers a large heterogeneity in virulence-associated genomic features among circulating isolates. The diphtheria toxin gene was observed in most isolates, which were all confirmed to produce the toxin in vitro except one, which was non-toxigenic toxin gene bearing (NTTB). However, three isolates were tox-negative, indicating that such isolates can cause diphtheria-like respiratory symptoms. Currently, with the important exception of

298 diphtheria toxin, the links between virulence genes of $\mathcal{C}$. diphtheriae strains and clinical expression are unknown [39]. Whereas two Yemen sublineages are of biovar Gravis, four were of biovar Mitis. Biovar Gravis isolates have been considered more virulent than biovar

301 Mitis isolates [40, 41]. Interestingly, our work reveals that the distribution of virulence302 associated genes is strongly contrasted between two major lineages of $C$. diphtheriae, which 303 were defined here by the presence of the Gravis-specific gene spuA. Our genomic data 304 suggest that inter-lineage heterogeneity in iron acquisition, adhesion and colonization 305 capacities may exist and could underlie epidemiological or clinical differences among them.

306 We found that patients infected with sublineage A, of biovar Gravis, tended to be younger 307 and with more frequent neck swelling. However, as neck swelling is more commonly 308 observed in young patients, we cannot disentangle sublineage and age effects here. The 
medRxiv preprint doi: https://doi.org/10.1101/2020.07.21.20159186; this version posted July 27, 2020. The copyright holder for this preprint (which was not certified by peer review) is the author/funder, who has granted medRxiv a license to display the preprint in perpetuity.

It is made available under a CC-BY-NC 4.0 International license.

309 underlying mechanisms of lymph node manifestations in diphtheria, described as nonspecific

310 acute lymphadenitis [1], are unknown. Future studies should investigate the impact of the

311 genomic diversity of $C$. diphtheriae on the pathogenicity and clinical expression of

312 diphtheria.

313 Genomic sequencing of bacterial pathogens is a powerful approach to define relationships

314 across time, sources and geography [42][15]. The $C$. diphtheriae genotypes observed in

315 Yemen were distinct from strains from the large ex-Soviet Union 1990s outbreak, whereas

316 no data exists on the strains involved in other recent outbreaks in Venezuela, Haiti and

317 Bangladesh. Migration and trade from the horn of Africa into Yemen are major drivers of

318 pathogenic strain spread, as observed for cholera [15]. The nearly complete lack of

319 information on circulating $C$. diphtheriae from neighboring countries has restricted our

320 ability to define the dynamics of geographic spread of $C$. diphtheriae in this world region.

321 However, a few $C$. diphtheriae genomes were linked epidemiologically and genetically to the

322 neighboring countries Somalia and Saudi Arabia.

323 We estimated the evolutionary rate of $C$. diphtheriae and found it is similar to other human

324 pathogens sampled over short time scales, such as Staphylococcus aureus or Streptococcus

325 pyogenes [43]. Our genomic data analyses thus imply that the diversification of the major

326 Yemen outbreak sublineage largely predates the detection of the outbreak by the disease

327 surveillance system. These observations concur with the multiplicity of sublineages that a

328 reservoir of $C$. diphtheriae diversity existed in Yemen before the outbreak recognition. We

329 note that our rate and age estimates have large confidence intervals, which is explained by

330 the small number of available genomes.

331 Although we provide a glimpse into the microbiological characteristics of diphtheria in

332 Yemen, the available samples of $\mathcal{C}$. diphtheriae sent for biological confirmation currently do

333 not provide a complete picture of the outbreak. Samples referred to NCPHL were distributed

334 across a large time period but governorates of the Southern part of the country were largely

335 under-represented, as $91 \%$ of confirmed samples came from Northern governorates (Table

336 S3). This limitation reflects the current situation of the country, divided by conflict into South

337 and North parts.

338 In summary, this work sheds light on epidemiological and clinical aspects of the current

339 Yemen diphtheria outbreak. We demonstrate high phylogenetic, genomic and phenotypic

340 variation of $C$. diphtheriae within a single outbreak, suggesting that the characterization of 
341 isolates at the level of individual patients or local chains of transmission is relevant for

342 patient management during diphtheria outbreaks. This underlines the need to reinforce

343 laboratory capacity in the context of diphtheria outbreaks. Concerted international efforts

344 should be developed aiming at enhancing surveillance and defining in real time the

345 characteristics of $C$. diphtheriae clinical isolates. Diphtheria is a largely forgotten disease, and

346 contemporaneous research into its pathophysiology is scarce. Further, in face of increasing

347 disruption of vaccination campaigns and the shortage of diphtheria antitoxin supply, studies

348 into the determinants of local persistence of $C$. diphtheriae and its spread at regional or

349 global scales are needed in order to better control the reemergence of this dreadful

350 pathogen. 
medRxiv preprint doi: https://doi.org/10.1101/2020.07.21.20159186; this version posted July 27, 2020. The copyright holder for this preprint (which was not certified by peer review) is the author/funder, who has granted medRxiv a license to display the preprint in perpetuity.

It is made available under a CC-BY-NC 4.0 International license .

\section{Methods}

\section{Definitions and surveillance data}

353 Probable cases were defined based on clinical examination: any person with illness

354 characterized by an adherent membrane on the tonsils, pharynx and/or nose and any one of 355 the following: laryngitis, pharyngitis or tonsillitis [31]. Confirmed cases were defined as a 356 probable case from which a $C$. diphtheriae isolate was cultivated in the NCPHL laboratory. 357 Probable cases were based on the health facility surveillance system and were compiled 358 from electronic diseases early warning system (eDEWS) releases of weekly reporting of 359 diphtheria cases [31]. For the vaccination coverage, we used the 2017 and 2018 annual 360 reports by the national Expanded Programme on Immunization (EPI), obtained from the 361 Ministry of Public Health and Population (MoPHP) of Yemen. The attack rate per age group 362 was calculated by dividing the number of cases of each age group by the size of the 363 population within each age group (source: https://www.census.gov/data364 tools/demo/idb/informationGateway.php).

Biological confirmation, clinical data and external microbiological and genomic analyses

367 A total of 888 throat swab samples were received by the NCPHL and analyzed using local 368 microbiological procedures (Supplementary data). Demographic data, prior vaccination, signs and symptoms and current antibiotic of patients were collected for all samples. A random selection of 98 samples available on July 2019 was sent to Institut Pasteur for external analyses (Supplementary data).

372

373 Data availability

374 The whole genome sequencing data generated in this study were deposited in the European

375 Nucleotide Archive (ENA) database and are accessible through the study PRJEB34206

376 (https://www.ebi.ac.uk/ena/data/view/PRJEB34206). Raw read data are available under the 377 accessions ERR4332853-96. Contig sequences are available under the accessions 378 CAJDXH01000000-CAJDYY01000000. 
medRxiv preprint doi: https://doi.org/10.1101/2020.07.21.20159186; this version posted July 27, 2020. The copyright holder for this preprint (which was not certified by peer review) is the author/funder, who has granted medRxiv a license to display the preprint in perpetuity.

It is made available under a CC-BY-NC 4.0 International license .

379

380

381

382

383

384

385

386

387

388

389

390

391

392

393

394

395

396

397

398

399

400

401

402

403

404

405

406

407

408

409

\section{Ethical statement}

Data were collected as part of routine case management under an emergency response mandate from the government of Yemen. The scientific committee of the NCPHL, Sana'a authorized the usage of the clinical data included in this study.

\section{Author contributions}

A.H., the NCPHL diphtheria outbreak working group (A.A.R, M.A.A., E.M.A.-A., N.M.A.-M., K.A.A, H.Z. A.-S., A.A.A.-S.), A.C-L., E.B., M.P.P. and M.L. performed the microbiological cultures of the isolates and their biochemical and molecular characterizations. F.D., G.D., N.L. and H.S. collated and analyzed the epidemiological data. A.H., G.D. and J.T. collated and analyzed the clinical data. A.C., V.B., M.H., J.G., N.Z. and S.B. analyzed the genomic data. H.M. provided the DIFT045 strain. S.B. and G. D. initially designed, and subsequently coordinated, the project. S.B. designed the microbiological aspects of the study and wrote the initial version of the manuscript. All authors provided input to the manuscript and reviewed the final version.

\section{Conflicts of interests}

The authors declare no competing interests.

\section{Acknowledgments}

We thank Dr Taha Almotuakel (Yemen Ministry of Health) for continuous support, and Isabelle Cailleau (Institut Pasteur) and the Medecins Sans Frontieres Organization for logistical support. The NCPHL also acknowledges the World Health Organization for providing some reagents used in this study. This work used the computational and storage services (TARS cluster) provided by the IT department at Institut Pasteur.

\section{Role of the funding source}

This work was supported financially by institutional funding from the NCPHL-Sana'a and Institut Pasteur. The French National Reference Center for Corynebacteria of the diphtheriae complex received support from Institut Pasteur and Public Health France (Santé publique France, Saint Maurice, France). This work was also supported financially by the French Government's Investissement d'Avenir program Laboratoire d'Excellence "Integrative Biology of Emerging Infectious Diseases" (ANR-10-LABX-62-IBEID). The funders had no role in the study design, collection, analysis, interpretation of the data and manuscript writing. Institut Pasteur and the NCPHL supported the decision to submit the paper for publication. 
medRxiv preprint doi: https://doi.org/10.1101/2020.07.21.20159186; this version posted July 27, 2020. The copyright holder for this preprint (which was not certified by peer review) is the author/funder, who has granted medRxiv a license to display the preprint in perpetuity.

It is made available under a CC-BY-NC 4.0 International license .

\section{$410 \quad$ Figure Legends}

411 Figure 1. Epidemic curve and geographic and temporal origins of the isolates.

412 A. Weekly numbers of suspected cases (purple), samples (light blue) and confirmed isolates

413 (dark blue) of diphtheria in Yemen from January 2017 to April 2020, with three epidemic 414 waves being highlighted. Sequenced isolates are shown below the epidemic curve, colored

415 according to their sublineages (see Figure 3). B and C. Geographical location of the 888

416 samples of this study (B) and of the 340 confirmed samples (C). D and E. Geographical 417 location of the suspected cases during the first epidemic wave (D) and the second epidemic 418 wave (E). The governorate maps of Yemen was created using a shape file approved by the 419 Humanitarian Country Team in October 2019 (https://data.humdata.org/dataset/yemen420 admin-boundaries).

421

422 Figure 2. Age profile of suspected cases.

423 A. Age distribution of suspected cases during the first and second waves. B. Attack rates per 424 age group, per wave. Red shows the first wave, green the second. The mean attack rate 425 during the two waves was 6.6 per 100,000 .

Figure 3. Phylogenetic analysis of Yemen isolates with their virulence and resistance 428 characteristics.

429 A. Phylogenetic tree of the Yemen isolates, with the distinction of 6 sublineages (A to F; 430 sublineage $A$ was subdivided into A.1 [A.1.1, A.1.2] and A.2). On the right of the tree, the 431 black squares denote a resistance phenotype, while a black circle denote the presence of the 432 tox-gene or other virulence-associated genes. Open squares denote an intermediate 433 resistance phenotype. Scale bar, 0.001 nucleotide substitutions per site. B. Detailed 434 phylogenetic tree of the sublineage A. Nodes' ages and $95 \% \mathrm{Cl}$ are shown at the nodes. Scale 435 bar, 0.000005 nucleotide substitutions per site (i.e., 1 substitution every 200,000 436 nucleotides, or approximately 10 substitutions per genome). 
medRxiv preprint doi: https://doi.org/10.1101/2020.07.21.20159186; this version posted July 27, 2020. The copyright holder for this preprint (which was not certified by peer review) is the author/funder, who has granted medRxiv a license to display the preprint in perpetuity.

It is made available under a CC-BY-NC 4.0 International license.

437

438

439

440

441

442

443

444

445

446

447

448

449

450

451

452

453

454

455

456

457

458

459

460

461

462

463

464

465

466

467

468

469

470

471

472

473

474

\section{References}

1. Hadfield TL, McEvoy P, Polotsky Y, Tzinserling VA, Yakovlev AA. The pathology of diphtheria. J Infect Dis 2000;181 Suppl 1:S116-120.

2. Sharma NC, Efstratiou A, Mokrousov I, Mutreja A, Das B, et al. Diphtheria. Nat Rev Dis Primer 2019;5:81.

3. Patey O, Bimet F, Riegel P, Halioua B, Emond JP, et al. Clinical and molecular study of Corynebacterium diphtheriae systemic infections in France. Coryne Study Group. J Clin Microbiol 1997;35:441-445.

4. Dittmann S, Wharton M, Vitek C, Ciotti M, Galazka A, et al. Successful control of epidemic diphtheria in the states of the Former Union of Soviet Socialist Republics: lessons learned. J Infect Dis 2000;181 Suppl 1:S10-22.

5. Rahman MR, Islam K. Massive diphtheria outbreak among Rohingya refugees: lessons learnt. J Travel Med;26. Epub ahead of print 1 January 2019. DOI: 10.1093/jtm/tay122.

6. Paniz-Mondolfi AE, Tami A, Grillet ME, Márquez M, Hernández-Villena J, et al. Resurgence of Vaccine-Preventable Diseases in Venezuela as a Regional Public Health Threat in the Americas. Emerg Infect Dis 2019;25:625-632.

7. Meinel DM, Kuehl R, Zbinden R, Boskova V, Garzoni C, et al. Outbreak investigation for toxigenic Corynebacterium diphtheriae wound infections in refugees from Northeast Africa and Syria in Switzerland and Germany by whole genome sequencing. Clin Microbiol Infect Off Publ Eur Soc Clin Microbiol Infect Dis 2016;22:1003.e1-1003.e8.

8. Scheifer C, Rolland-Debord C, Badell E, Reibel F, Aubry A, et al. Re-emergence of Corynebacterium diphtheriae. Med Mal Infect 2019;49:463-466.

9. Dureab F, Müller O, Jahn A. Resurgence of diphtheria in Yemen due to population movement. J Travel Med;25. Epub ahead of print 1 January 2018. DOI: 10.1093/jtm/tay094.

10. Dureab F, Al-Sakkaf $\mathbf{M}$, Ismail $\mathbf{O}$, Kuunibe N, Krisam J, et al. Diphtheria outbreak in Yemen: the impact of conflict on a fragile health system. Confl Health 2019;13:19.

11. WHO. Diphtheria - Yemen. Disease Outbreak News. https://www.who.int/csr/don/22december-2017-diphtheria-yemen/en/ (2017).

12. OCHA. Yemen: Diphtheria Outbreak - Nov 2017. https://reliefweb.int/disaster/ep-2017-000175yem (2017).

13. Meyer D. Yemen-- First cholera, now diphtheria. https://www.outbreakobservatory.org/outbreakthursday-1/11/30/2017/yemen-first-choleranow-diphtheria (2017).

14. WHO-EMRO. Weekly Epidemiological Monitor, Volume 10, Issue 47 (19 November 2017). https://reliefweb.int/report/yemen/who-emro-weekly-epidemiological-monitor-volume-10issue-47-19-november-2017 (2017).

15. Weill F-X, Domman D, Njamkepo E, Almesbahi AA, Naji M, et al. Genomic insights into the 2016-2017 cholera epidemic in Yemen. Nature 2019;565:230-233. 
medRxiv preprint doi: https://doi.org/10.1101/2020.07.21.20159186; this version posted July 27, 2020. The copyright holder for this preprint (which was not certified by peer review) is the author/funder, who has granted medRxiv a license to display the preprint in perpetuity.

It is made available under a CC-BY-NC 4.0 International license .

475

476

477

478

479

480

481

482

483

484

485

486

487

488

489

490

491

492

493

494

495

496

497

498

499

500

501

502

503

504

505

506

507

508

509

510

511

512

513

16. Dureab F, Al-Awlaqi S, Jahn A. COVID-19 in Yemen: preparedness measures in a fragile state. Lancet Public Health 2020;5:e311.

17. Dhabaan GN, Al-Soneidar WA, Al-Hebshi NN. Challenges to testing COVID-19 in conflict zones: Yemen as an example. J Glob Health 2020;10:010375.

18. eDEWS. Electronic Integrated Disease Early Warning and Response System, Volume 08, Issue19, Epi week 19,(04- 10 May,2020).

19. Wagner KS, Stickings P, White JM, Neal S, Crowcroft NS, et al. A review of the international issues surrounding the availability and demand for diphtheria antitoxin for therapeutic use. Vaccine 2009;28:14-20.

20. Kneen R, Pham NG, Solomon T, Tran TM, Nguyen TT, et al. Penicillin vs. erythromycin in the treatment of diphtheria. Clin Infect Dis Off Publ Infect Dis Soc Am 1998;27:845-850.

21. Badell E, Guillot S, Tulliez M, Pascal M, Panunzi LG, et al. Improved quadruplex real-time PCR assay for the diagnosis of diphtheria. J Med Microbiol 2019;68:1455-1465.

22. Santos AS, Ramos RT, Silva A, Hirata R, Mattos-Guaraldi AL, et al. Searching whole genome sequences for biochemical identification features of emerging and reemerging pathogenic Corynebacterium species. Funct Integr Genomics 2018;18:593-610.

23. Hennart M, Panunzi LG, Rodrigues C, Gaday Q, Baines SL, et al. Population genomics and antimicrobial resistance in Corynebacterium diphtheriae. bioRxiv 2020;2020.05.19.101030.

24. Martini H, Soetens O, Litt D, Fry NK, Detemmerman L, et al. Diphtheria in Belgium: 2010-2017. J Med Microbiol 2019;68:1517-1525.

25. Cerdeño-Tárraga AM, Efstratiou A, Dover LG, Holden MTG, Pallen M, et al. The complete genome sequence and analysis of Corynebacterium diphtheriae NCTC13129. Nucleic Acids Res 2003;31:6516-6523.

26. Berger A, Dangel A, Schober T, Schmidbauer B, Konrad R, et al. Whole genome sequencing suggests transmission of Corynebacterium diphtheriae-caused cutaneous diphtheria in two siblings, Germany, 2018. Euro Surveill Bull Eur Sur Mal Transm Eur Commun Dis Bull;24. Epub ahead of print January 2019. DOI: 10.2807/1560-7917.ES.2019.24.2.1800683.

27. Trost E, Tauch A. Comparative genomics and pathogenicity islands of Corynebacterium diphtheriae, Corynebacterium ulcerans, and Corynebacterium pseudotuberculosis. In: Corynebacterium diphtheriae and related toxigenic species: genomics, pathogenicity and applications. Burkovski, A. Ed.; Springer; 2014. pp. 39-65.

28. Timms VJ, Nguyen T, Crighton T, Yuen M, Sintchenko V. Genome-wide comparison of Corynebacterium diphtheriae isolates from Australia identifies differences in the Pan-genomes between respiratory and cutaneous strains. BMC Genomics 2018;19:869.

29. Qian Y, Lee JH, Holmes RK. Identification of a DtxR-regulated operon that is essential for siderophore-dependent iron uptake in Corynebacterium diphtheriae. J Bacteriol 2002;184:48464856.

30. Ogwang S, Nguyen HT, Sherman M, Bajaksouzian S, Jacobs MR, et al. Bacterial conversion of folinic acid is required for antifolate resistance. J Biol Chem 2011;286:15377-15390. 
medRxiv preprint doi: https://doi.org/10.1101/2020.07.21.20159186; this version posted July 27, 2020. The copyright holder for this preprint (which was not certified by peer review) is the author/funder, who has granted medRxiv a license to display the preprint in perpetuity. It is made available under a CC-BY-NC 4.0 International license.

31. Dureab F. The usefulness of the electronic Disease Early Warning System (eDEWS) in the humanitarian crisis of Yemen. University of Heidelberg. https://archiv.ub.uniheidelberg.de/volltextserver/27986/ (2019).

32. Dash N, Verma S, Jayashree M, Kumar R, Vaidya PC, et al. Clinico-epidemiological profile and predictors of outcome in children with diphtheria: a study from northern India. Trop Doct 2019;49:96-101.

33. Blumberg LH, Prieto MA, Diaz JV, Blanco MJ, Valle B, et al. The Preventable Tragedy of Diphtheria in the 21st Century. International journal of infectious diseases[]: IJID]: official publication of the International Society for Infectious Diseases;71. Epub ahead of print June 2018. DOI: 10.1016/j.jijid.2018.05.002.

34. Murhekar M. Epidemiology of Diphtheria in India, 1996-2016: Implications for Prevention and Control. Am J Trop Med Hyg 2017;97:313-318.

35. Galazka A. The changing epidemiology of diphtheria in the vaccine era. J Infect Dis 2000;181 Suppl 1:S2-9.

36. OCHA-services. Diphtheria vaccination campaign for 2.7 million children concludes in Yemen. https://reliefweb.int/report/yemen/diphtheria-vaccination-campaign-27-million-childrenconcludes-yemen (2018).

37. WHO-EMRO. Situation Report, September 2019, Issue NO.9: Yemen Conflict. https://reliefweb.int/sites/reliefweb.int/files/resources/Yem-Sitrep-Sept-2019.pdf (2019).

38. Zasada AA. Antimicrobial susceptibility and treatment. In: Corynebacterium diphtheriae and related toxigenic species genomics, pathogenicity and applications. Burkovski A., editor. New York: Springer; 2014. pp. 239-246.

39. Sangal V, Hoskisson PA. Evolution, epidemiology and diversity of Corynebacterium diphtheriae: New perspectives on an old foe. Infect Genet Evol J Mol Epidemiol Evol Genet Infect Dis 2016;43:364-370.

40. McLeod JW. THE TYPES MITIS, INTERMEDIUS AND GRAVIS OF CORYNEBACTERIUM DIPHTHERIAE: A Review of Observations during the Past Ten Years. Bacteriol Rev 1943;7:1-41.

41. Barksdale L. Corynebacterium diphtheriae and its relatives. Bacteriol Rev 1970;34:378-422.

42. Moura A, Criscuolo A, Pouseele H, Maury MM, Leclercq A, et al. Whole genome-based population biology and epidemiological surveillance of Listeria monocytogenes. Nat Microbiol 2016;2:16185.

43. Duchêne S, Holt KE, Weill F-X, Le Hello S, Hawkey J, et al. Genome-scale rates of evolutionary change in bacteria. Microb Genomics 2016;2:e000094. 
medRxiv preprint doi: https://doi.org/10.1101/2020.07.21.20159186; this version posted July 27, 2020. The copyright holder for this preprint (which was not certified by peer review) is the author/funder, who has granted medRxiv a license to display the preprint in perpetuity.

It is made available under a CC-BY-NC 4.0 International license.

548 Table 1. Clinical characteristics of patients infected by sublineage A or other sublineages

549 circulating in Yemen

\begin{tabular}{|l|c|c|c|}
\hline Characteristics, (\%) otherwise stated & $\begin{array}{c}\text { Sublineage A } \\
\mathrm{N}=28\end{array}$ & $\begin{array}{c}\text { Other sublineages } \\
\mathrm{N}=14\end{array}$ & P value* \\
\hline Age, years, median (range) & $8(2-35)$ & $14(2-35)$ & 0.06 \\
\hline Male & $14(50)$ & $5(36)$ & 0.38 \\
\hline History of previous vaccination & $11(44)$ & $7(64)$ & 0.24 \\
\hline Fever & $28(100)$ & $14(100)$ & - \\
\hline Pseudomembrane & $28(100)$ & $14(100)$ & \\
\hline Neck swelling & $22(84)$ & $4(33)$ & 0.002 \\
\hline
\end{tabular}

550 * Differences between cases infected with $C$. diphtheriae sublineage A compared to the ones

551 infected with isolates from other sublineages (B, C, D, E or F) were assessed by the Mann-

552 Whitney $U$ test, the Student's t test, the $\chi 2$ method, and Fisher's exact test where

553 appropriate. 


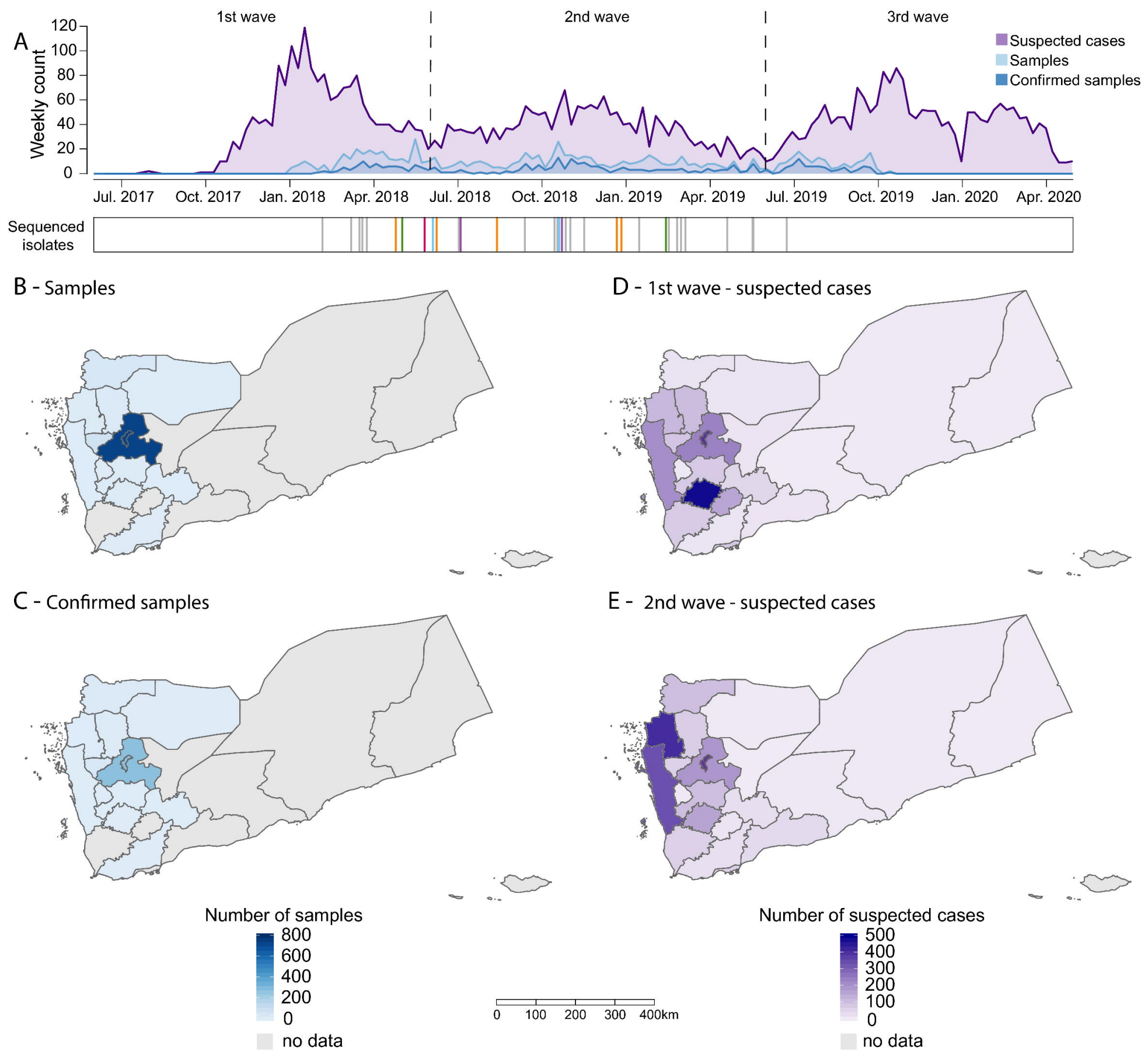


A Age distribution of suspected cases

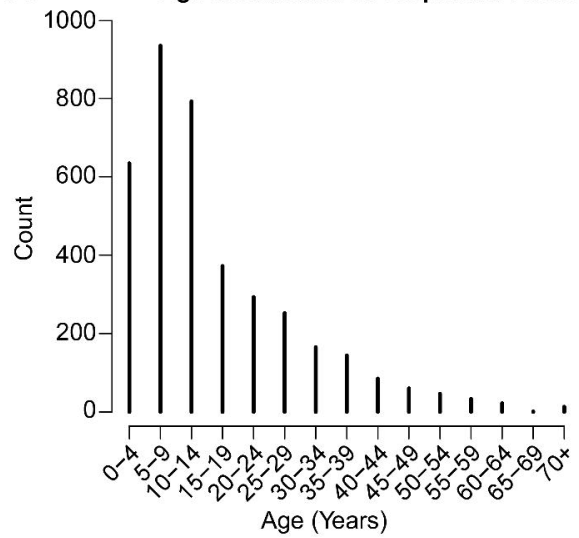

B Changes in attack rates per age group

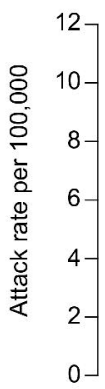

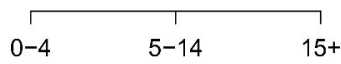

1st wave

2nd wave

Age (Years) 


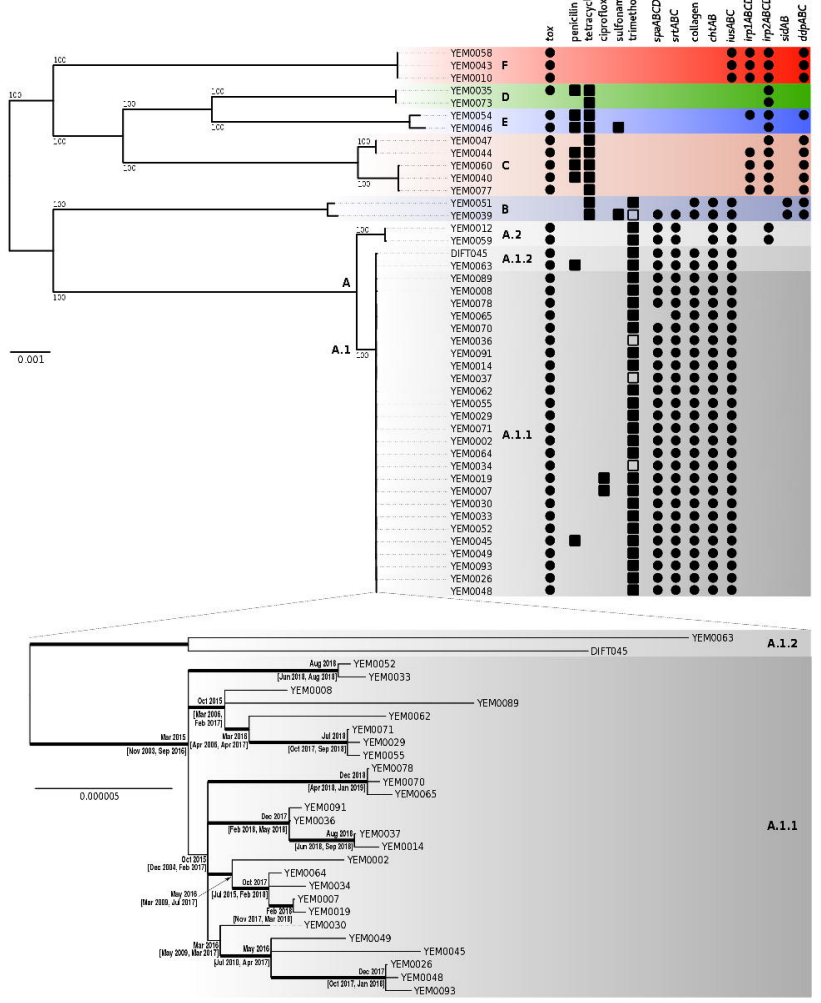

